\title{
KEMAMPUAN MENULIS CERITA DI SD
}

\author{
Uyu Mu'awwanah \\ Dosen PGMI IAIN Sultan Maulana Hasanuddin Banten \\ Surel : uyumuawwanah@yahoo.co.id
}

\begin{abstract}
The ability Writing At SD. Writing is one of the capabilities that need to be owned by the elementary school students. By having the ability to write, students can communicate ideas, appreciation and experience to the various parties, regardless of the bonding time and place. The ability to write as well as with other language skills, can be owned through mentoring and intensive training. Exercise writing skills in primary school is very important because it is a basic planting writing. Basic training is crucial to the ability of students to write further. If you've basically solid, writing that somehow that will be developed will not be a problem anymore. Therefore, the ability to write it must be nurtured and enhanced intensive. The habit of writing, including writing scientific papers, should be developed from the primary level to college. Given the importance of learning to write in elementary school, the teacher must truly understand the aspects of writing in primary school.
\end{abstract}

Keywords: writing, story and SD

\begin{abstract}
Abstrak : Kemampuan Menulis Cerita Di SD. Menulis merupakan salah satu kemampuan yang perlu dimiliki oleh siswa Sekolah Dasar. Dengan memiliki kemampuan menulis, siswa dapat mengkomunikasikan ide, penghayatan dan pengalamannya ke berbagai pihak, terlepas dari ikatan waktu dan tempat. Kemampuan menulis seperti juga halnya dengan kemampuan berbahasa yang lain dapat dimiliki melalui bimbingan dan latihan yang intensif. Latihan kemampuan menulis di Sekolah Dasar sangat penting karena merupakan penanaman dasar menulis. Latihan dasar ini sangat menentukan kemampuan siswa dalam menulis lanjut. Kalau dasarnya sudah kokoh, tulisan yang bagaimanapun yang akan dikembangkan tidak akan menjadi persoalan lagi. Oleh karena itu, kemampuan menulis ini harus dibina dan ditingkatkan secara intensif. Kebiasaan menulis, termasuk menulis karya ilmiah, harus dikembangkan dari tingkat pendidikan dasar sampai ke perguruan tinggi. Mengingat sangat pentingnya pelajaran menulis di Sekolah Dasar, maka guru harus betul-betul memahami aspek-aspek menulis di Sekolah Dasar.
\end{abstract}

Kata Kunci: Menulis, Cerita, SD

\section{PENDAHULUAN}

Guru Sekolah Dasar harus betulbetul memahami hakikat pengajaran menulis di Sekolah Dasar. Kemudian harus pula mampu merencanakan proses belajar-mengajar yang efektif sesuai dengan pokok bahasannya. Strategi pembelajaran yang dipilih harus dapat mencapai tujuan yang sudah ditetapkan. Tujuan pengajaran menulis tentulah mengharapkan siswa Sekolah Dasar memiliki kemampuan menulis, baik menulis permulaan maupun menulis lanjut. Oleh karena itu, peranan latihan dan bimbingan yang intensif sangat dituntut. Apalagi mengingat pengajaran kemampuan menulis di Sekolah Dasar ini merupakan dasar untuk menulis di sekolah lanjutan. Kalau dasarnya sudah kuat dan kokoh, tentu pengembangan bentuk tulisan bagaimanapun yang akan dikembangkan tidak menjadi masalah lagi.Memiliki kemampuan menulis memungkinkan manusia mengkomunikasikan ide, penghayatan dan pengalaman ke berbagai pihak, terlepas dari ikatan waktu dan tempat. Pada umumnya ilmu pengetahuan, 
peristiwa-peristiwa penting, penemuanpenemuan, kita peroleh melalui tulisan. Demikian juga, melalui tulisan kita mendapatkan hiburan, misalnya dengan membaca bermacam-macam karya fiksi, baik cerpen, novel maupun roman.

Kemampuan menulis seperti juga halnya kemampuan berbahasa yang lain, dapat dimiliki melalui latihan dan bimbingan yang intensif. Kemampuan menulis ini sudah mulai dilatihkan di tingkat Sekolah Dasar. Di tingkat Sekolah Dasar mulai ditanamkan dasardasar kemampuan menulis ini. Kalau dasarnya sudah kuat dan kokoh, tentu bentuk karangan yang bagaimanapun yang akan dikembangkan tidak menjadi persoalan lagi.

Berbeda dengan kemampuan yang lain, kemampuan berbahasa, khususnya kemampuan menulis, pada awal siswa disuruh menulis atau mengarang; semua komponen yang membangun karangan itu sekaligus sudah dituntut. Itulah sebabnya kemampuan menulis itu dikatakan sangat kompleks. Pada awal siswa mulai mengarang, yaitu di kelas IV, ia sudah dituntut mampu mengemukakan ide/pesan dengan ejaan yang benar, dengan kosakata yang tepat, dengan kalimat yang efektif, dan dengan paragraf yang baik. Berarti, siswa Sekolah Dasar ini sudah dituntut mampu menggunakan ejaan, kosakata, dan mampu membuat kalimat dan menghubung-hubungkan kalimat dalam satu paragraf sesuai dengan tingkat kemampuan siswa SD. Itulah sebabnya dikatakan kemampuan menulis itu sangat kompleks.

\section{Menulis di Sekolah Dasar}

Seperti kita ketahui, kemampuan menulis tidak diperoleh secara alamiah tetapi melalui proses belajar-mengajar. Untuk dapat menuliskan huruf sebagai lambang bunyi, siswa harus berlatih dan cara memegang alat tulis serta menggerakkan tangannya dengan memperhatikan apa yang harus dituliskan (digambarkan). Siswa harus dilatih mengamati lambang bunyi itu, memahami setiap huruf sebagai lambang bunyi tertentu, sampai menuliskannya dengan benar. Agar bermakna, proses belajar menulis permulaan ini dilaksanakan setelah siswa mampu mengenali huruf-huruf itu.

Kemudian dalam kegiatan menulis lanjut, barulah siswa berlatih mengungkapkan gagasannya secara tertulis. Pengajaran menulis di Sekolah Dasar harus dapat membekali siswa dengan kemampuan dasar menulis. Pengajaran ini mencakup pengajaran kemampuan menulis permulaan dan menulis lanjut. Sejalan dengan pengajaran membaca permulaan, pengajaran menulis permulaan berakhir di kelas II. Pengajaran menulis dalam arti mengarang yang sebenarnya baru dimulai di kelas IV. Di kelas, ketiga pengajaran menulis ditekankan pada latihan penerapan ejaan.

Pengembangan kemampuan menulis di Sekolah Dasar banyak bergantung kepada kreativitas seorang guru. Oleh karena itu, guru harus membekali dirinya dengan kemampuan menulis. Guru pun dituntut mampu memilih metode yang sesuai sehingga dapat merangsang kreativitas siswa. Di samping itu seperti sudah diutarakan sebelumnya, perlu diingat kemampuan menulis hanya dapat dicapai dengan berlatih. Latihan yang intensif dan bimbingan yang terarah, tentulah akan menggiring siswa memiliki kemampuan menulis, sesuai dengan tujuan yang ingin dicapai. Dalam hal ini setiap guru hendaknya menyadari bahwa pengajaran 
menulis tidak ditekankan pada pengetahuan kebahasaan tetapi bagaimana menerapkan pengetahuan tersebut.

Kalau kita perhatikan materi di Sekolah Dasar bidang studi Bahasa Indonesia, semua kemampuan dasar menulis itu sudah tercantum. Pengenalan huruf, baik huruf besar maupun huruf kecil diberikan dan kelas I sampai kelas II. Kemudian, di kelas III, khusus mengenai ejaan, walaupun belum tuntas semuanya. Di kelas IV sudah mulai dengan pengembangan ide atau gagasan dengan menggunakan ejaan yang benar, misalnya menulis karangan berbentuk prosa narasi sederhana, menulis karangan prosa deskripsi, dan membuat surat pribadi. Di kelas V sudah diajarkan bagaimana memilih judul untuk sebuah karangan, memecah judul tersebut menjadi topiktopik yang lebih kecil atau menyusun karangka karangan, kemudian dilanjutkan dengan pengembangan paragraf. Di samping itu, juga ada pokok-pokok bahasan yang berkaitan dengan apresiasi sastra, misalnya membuat puisi atau mengubah bentuk puisi menjadi bentuk prosa. Di kelas VI, perluasan pokok bahasan sebelumnya yang penekanannya pada pengembangan bermacam-macam karangan, seperti: narasi, deskripsi, eksposisi, argumentasi dan persuasi.

Kalau kita perhatikan pokokpokok bahasan dari kelas I sampai kelas VI ini, sebetulnya tidak berbeda dengan pokok bahasan yang ada pada jenjang pendidikan yang lebih tinggi yaitu SLTP dan SLTA. Kalau di tingkat Sekolah Dasar sudah diberikan dasar-dasarnya, di tingkat pendidikan lanjutan tinggal memperluas dan memperdalam. Secara berkelanjutan guru juga bebas berimprovisasi dalam memberikan materi yang sesuai dengan aspek perkembangan peserta didik, beragam, dan relevan. Materi pelajaran disusun dengan memperhatikan kesinambungan, keluasan, dan kedalaman materi. Kesinambungan dimaksudkan bahwa materi pelajaran bahasa Indonesia di susun dengan memperhatikan jenjang, semester, kelas, jenis sekolah (SD, SMP, SMA). Dengan keluasan dan kedalaman, dimaksudkan bahwa materi itu disusun dengan memperhatikan perbedaan keluasan dan kedalamannya di setiap program, semester, kelas dan jenis sekolah. Jadi, perbedaannya hanya terletak pada keluasan dan kedalamannya. Makin tinggi tingkatannya, makin luas dan mendalam bahannya. Inilah yang di maksud mengikuti dasar spiral dalam pengembangan kurikulum. (Muslich. 2007: 18)

Kita harus ingat, tingkat Sekolah Dasar merupakan tingkat pertama penanam dasar semuanya itu. Kalau dasarnya sudah kuat, tentu perluasan dan pedalaman materi di tingkat selanjutnya tidak akan mengalami kesulitan.

\section{Tujuan Pembelajaran Menulis di SD}

Selaras dengan semangat pemerintah membentuk Badan Standar Nasional Pendidikan (BSNP) dalam memberikan informasi dan keleluasaan (otonomi) kepada guru bahasa Indonesia tentang pengalaman belajar yang perlu diusahakan bagi siswa dengan penyajian pokok bahasan, subpokok bahasan, atau materi tertentu, sesuai dengan prinsipprinsip K13. Setidaknya kompetensi dasar dalam pembelajaran menulis di SD bisa diklassifikasikan seperti di bawah ini.

\section{Kelas I dan II}

Siswa memahami cara menulis permulaan dengan mengunakan ejaan 
yang benar dan dapat menyatakan ide/pesan secara tertulis.

Kompetensi ini sama sampai kelas II dengan pokok bahasan yang sama, yaitu menulis permulaan. Untuk kelas I, penekanannya pada cara menuliskan huruf dari a sampai $\mathrm{z}$ dalam konteks kalimat sederhana. Diharapkan siswa dapat menuliskan huruf dari a sampai $\mathrm{z}$ dengan tepat.

$\begin{array}{ccr}\text { Sesuai } & \text { dengan } & \text { prinsip } \\ \text { kesinambungan, } & \text { keluasan } & \text { dan }\end{array}$ kedalaman untuk kelas dua, tujuan tersebut dilanjutkan dan dikembangkan. Dengan ini siswa diharapkan dapat: menuliskan huruf kapital untuk huruf pertama kata awal kalimat dengan tepat;

a. menggunakan tanda baca dengan tepat;

b. menuliskan kata-kata berstruktur fonem KKV dan KKVK dengan tepat;

c. menuliskan kata-kata yang mengandung diftong yang mendapat akhiran -an dan -kan;

d. menuliskan kata yang berakhiran dengan konsonan $\mathrm{k}$ yang mendapat akhiran -an dan -kan dengan tepat.

Tentu penekanan pengajaran menulis dan kelas I dan II ini baru pada cara atau teknik menuliskan atau menggambarkan huruf-huruf di atas, belum menekankan pada pemakaiannya. Tetapi yang jelas guru mempunyai otonomi dalam memberikan yang terbaik pada siswanya.

\section{Kelas III}

Pokok bahasan untuk kelas III, bisa saja khusus mengenai ejaan. Kompetensinya dapat dirangkum sebagai berikut. Siswa memahami cara menuliskan: huruf besar, tanda hubung, kata berimbuhan, kata gabung, kata ulang, $\mathrm{ku} / \mathrm{mu} / \mathrm{kau} / \mathrm{nya}, \quad$ kata yang bersuku, kata berawalan, kata berakhiran, tanda petik, kata depan dengan ejaan yang benar dan dapat menyatakan ide/pesan secara tertulis.

Nah, kalau kita perhatikan rangkuman Kompetensi untuk kelas III di atas, tentu setelah menyelesaikan kelas III Sekolah Dasar, siswa diharapkan telah dapat menuliskan kata dengan ejaan sesuai dengan Pedoman Umum Ejaan Bahasa Indonesia Yang Disempurnakan walaupun belum semua peraturan tentang cara penulisan huruf, kata dan tanda baca yang ada dalam Pedoman Umum Ejaan Bahasa Indonesia Yang Disempurnakan, diberikan, namun penulisan huruf, kata dan tanda baca yang diperlukan untuk siswa SD tercakup.

Para guru harus memperhatikan dengan seksama, kemudian mencoba merumuskan kompetensi dasar, dan mempersiapkan bahan materi serta merencanakan pengalaman belajar yang menyenangkan bagi siswa.

\section{Kelas IV}

Setelah siswa dapat menuliskan atau menggambarkan huruf, kemudian dapat menuliskan bermacam-macam kata dalam kalimat dengan ejaan yang tepat sesuai dengan yang diajarkan di kelas I, II, III maka di kelas IV pokok bahasan menulis ini dilanjutkan dengan menulis lanjut, sesuai dengan prinsip keluasan dan kedalaman. Kompetensi yang ingin dicapai dapat dikelompokkan seperti di bawah ini:

a. siswa memahami cara menulis prosa, narasi, deskripsi dengan ejaan yang benar dan dapat menyatakan ide/pesan secara tertulis.

b. siswa memahami cara menulis surat pribadi, surat izin, surat ucapan selamat, surat undangan, surat ucapan, surat ajakan dengan ejaan yang benar dan dapat menyatakan ide/pesan secara tertulis. 
c. siswa memahami cara menulis kata serapan dengan ejaan yang benar dan dapat menyatakan ide/ pesan secara tertulis.

d. siswa memahami cara mengisi/menulis formulir permohonan dengan ejaan yang benar dan dapat menyatakan ide/pesan secara tertulis.

Keempat Kompetensi inilah yang ingin dicapai dalam pengajaran pokok bahasan menulis di kelas IV. Siswa diharapkan dapat menulis prosa narasi sederhana, seperti pengalamannya sehari-hari dan siswa juga diharapkan dapat menulis prosa deskripsi sederhana tentang lingkungan hidup. Dalam hal ini tentu bukan lagi sekedar dapat menggambarkan huruf dengan ejaan yang benar, tetapi sudah lanjut dengan mengembangkan ide atau gagasan dengan ejaan yang benar. Di sini siswa sudah dituntut menghubungkan gagasan atau ide yang satu dengan ide yang lain.

Demikian pula hal nya dengan pokok bahasan bermacam-macam surat. Siswa diharapkan dapat menulis bermacam-macam surat dan mengisi formulir permohonan dengan ejaan yang benar. Pengembangan ide atau pesan dalam hal ini juga sudah dituntut. Guru berusaha untuk memberikan contoh bermacam-macam surat yang cocok untuk siswa kelas IV.

Kompetensi lain yaitu dapat menuliskan kata serapan dengan ejaan yang benar, yang merupakan lanjutan dari Kompetensi di kelas III tentang ejaan dan terbatas pada kata serapan yang sesuai dengan tingkat kosakata siswa Sekolah Dasar.

Selanjutnya guru juga mencoba merumuskan kompetensi dasar berdasarkan indikator-indikator yang harus ada dalam pokok bahasan yang tercakup di dalamnya.

\section{Kelas V}

Tujuan pengajaran menulis di kelas V ini sudah ditekankan pada menulis lanjut (pedalaman). Kompetensi untuk menulis ini dapat kita kelompokkan sebagai berikut:

a. siswa memahami cara menulis paragraf dengan ejaan yang benar dan dapat menyatakan ide/ pesan secara tertulis.

b. siswa memahami cara menulis karangan dengan ejaan yang benar dan dapat menyatakan ide/ pesan secara tertulis. Tujuan ini dijabarkan dengan beberapa pokok bahasan, mulai dari memilih judul karangan, memecahnya menjadi topik-topik yang lebih kecil atau menyusun karangan yang berbentuk argumentasi, deskripsi dan persuasi.

c. siswa memahami cara menulis pantun, puisi baru, mengubah puisi menjadi prosa, menyingkat isi cerita fiksi, dan mengembangkan judul cerita fiksi. Tentu Tujuan ini, selain memperdalam kemampuan menulis paragraf, juga meningkatkan apresiasi siswa tentang sastra, baik puisi maupun prosa.

d. siswa memahami cara menulis laporan dengan ejaan yang benar dan dapat mengatakan ide/ pesan secara tertulis. Tujuan ini dijabarkan dengan pokok bahasan menyusun bermacammacam laporan hasil pengamatan. Jadi, melaporkan fakta, misalnya kecelakaan lalu lintas, pertandingan olahraga, berkemah dan sebagainya sesuai dengan tingkat pengetahuan siswa Sekolah Dasar.

e. siswa memahami cara menulis prosa deskripsi dan persuasi dengan ejaan yang benar dan dapat menyatakan ide/pesan secara tertulis. Selain siswa diharapkan mampu menulis prosa deskripsi dan persuasi sederhana, 
Jurnal Guru Kita (JGK). Vol 1 (2) Maret 2017, hlm. 26-39

tujuan ini juga sekaligus melatih kemampuan siswa menulis paragraf tentunya, karena mengarang atau menulis yang paling pendek itu dilahirkan dalam bentuk paragraf.

\section{Kelas VI}

Tujuan pengajaran menulis di tingkat terakhir di Sekolah Dasar ini bukan lagi sekedar siswa dapat menyampaikan ide atau pesan secara tertulis, melainkan sudah menekankan pada aspek komunikasi. Misalnya, bagaimana menyusun sebuah tulisan yang dapat dimuat dalam media cetak atau melalui radio. Di samping itu, juga menulis lanjut dengan pengembangan bermacam-macam karangan seperti: eksposisi, argumentasi, deskripsi dan narasi.

Kompetensi yang ingin dicapai dapat dirangkum seperti di bawah ini.

a. Siswa menulis prosa eksposisi dengn ejaan yang benar dan dapat menyatakan ide/pesan secara tertulis. Tujuan ini dijabarkan dengan pokok bahasan menulis naskah berita keluarga, menulis telegram, menulis pengumuman, mengisi blangko wesel, menyusun bermacam-macam naskah pidato. Nah, selanjutnya kita susun kompetensi dasar dari setiap pokok bahasan tersebut.

b. Siswa menulis prosa deskripsi dengan ejaan yang benar dan dapat menyatakan ide/pesan secara tertulis.

c. Siswa menulis prosa argumentasi dengan ejaan yang benar dan dapat menyatakan ide/pesan secara tertulis.

d. Siswa menulis prosa persuasi dengan ejaan yang benar dan dapat menyatakan ide/pesan secara tertulis.
Keempat bentuk karangan baik eksposisi, deskripsi, narasi dan argumentasi/persuasi, telah diajarkan kepada siswa, Tentu pokok bahasannya disesuaikan dengan tingkat Sekolah Dasar. Mereka diperkenalkan bagaimana menyusun bermacam-macam pidato, membuat bermacam-macam pengumuman, laporan, iklan, poster, dilatih menyusun alasan atau fakta yang masuk akal (logis), dan menyusun tulisan untuk dapat mempengaruhi orang lain.

Tujuan yang berkaitan dengan apresiasi bahasa dan sastra tergambar dalam tujuan siswa memahami cara menulis drama dengan ejaan yang benar dan dapat menyatakan ide/pesan secara tertulis.

Siswa SD Kelas VI tentu sudah mengenal dialog atau percakapan. Dengan memberikan wacana tertentu, siswa dapat dilatih menyusun dialog sehingga menjadi sebuah karangan yang berbentuk drama.

Semua rumusan tujuan di atas, dari kelas I sampai kelas VI, selain ditekankan agar siswa dapat menulis dan mengutarakan ide/pesan secara tertulis, juga ditekankan agar siswa dapat menggunakan ejaan yang benar. Dengan demikian, diharapkan lulusan siswa Sekolah Dasar ini telah memilih kemampuan dasar dalam menulis yang dapat dilanjutkan ke jenjang pendidikan lanjut dengan memperhatikan kesinambungan, keluasan dan kedalaman.

\section{Pembelajaran Menulis di SD Menulis Permulaan}

Kita semua menyadari betapa pentingnya menulis permulaan ini. Pokok bahasan menulis permulaan seperti yang sudah dijelaskan sebelumnya diberikan sampai kelas II. 
Kita pun memahami tujuan pelajaran menulis ini adalah agar siswa dapat menulis dengan tulisan yang terang, jelas, teliti dan mudah dibaca.

Pada prinsipnya membaca dan menulis permulaan berjalan seiring. Sebelum mulai membimbing anak untuk membaca/menulis permulaan, sangat diperlukan persiapan yang memadai. Persiapan tersebut antara lain harus mengenal langkah-langkah yang harus ditempuh. Selain itu, juga perlu menganalisis bahan yang akan disajikan, alat peraga yang menunjang, dan tujuan yang ingin dicapai.

Tujuan menulis permulaan tentu tidak terlepas dari tujuan pengajaran bahasa Indonesia khususnya. Menulis permulaan adalah tujuan sementara, yang kemudian diharapkan siswa akan berkembang dan menggunakan kemampuan menulisnya untuk menambah pengetahuan dan mengembangkan pribadinya lebih lanjut. Namun, kita menyadari menulis permulaan ini merupakan dasar dari menulis lanjut. Menulis lanjut baru dimulai di kelas IV.

Dalam menulis permulaan diterapkan dasar metode SAS. Bahan yang diberikan mengandung makna dan bertitik tolak dari pengalaman anak. Pelajaran dimulai dengan struktur bahasa yang bermakna, yaitu kalimat. Kemudian, unsur-unsurnya dianalisis, disintesiskan lagi menjadi struktur kalimat. Kita harus ingat, tidak dibenarkan mengajarkan nama huruf seperti lazimnya digunakan dalam metode eja.

Pada menulis permulaan, penekanan tujuannya adalah pada mampu menulis dengan terang, jelas, teliti dan mudah dibaca. Kemampuan ini tidak diperoleh secara alamiah. pada tahap permulaan, kemampuan ini memerlukan proses belajar. Untuk dapat menuliskan huruf sebagai lambang bunyi, siswa harus berlatih cara memegang alat tulis serta menggerakkan tangannya dengan memperhatikan apa yang harus dituliskan (digambarkan). Mereka juga harus dilatih menerapkan ejaan sesuai dengan Pedoman Umum Ejaan Bahasa Indonesia Yang Disempurnakan. Condong tulisan tidak bermacam-macam. Mereka harus mampu menulis tulisan tegak sebagai tulisan yang sudah dibakukan. Tulisan yang rapi dan indah sangat benar artinya dan hal ini erat hubungannya dengan kebiasaan.

Latihan menulis permulaan ini dilaksanakan bersama-sama dengan membaca permulaan. Siswa terlebih dahulu mengenali huruf-huruf dalam kata dan kalimat, kemudian berlatih menuliskannya. Misalnya, pertama, dapat menuliskan huruf a, i. n, m yang terdapat pada kata-kata dalam kalimat. Kemudian, dilanjutkan dengan hurufhuruf lain. Tentang pelajaran menulis permulaan ini, siswa dikenalkan huruf cetak dan huruf tegak bersambung. Pada dasarnya siswa pertama-tama disuruh menyalin dulu contoh yang diberikan berulang-ulang sampai siswa dapat menuliskannya dengan baik.

Demikianlah seterusnya siswa harus dilatih semua pokok bahasan yang berkaitan dengan menulis permulaan/ejaan dari kelas I sampai kelas III.

Ada beberapa langkah untuk pembelajaran menulis permulaan ;
a. Menentukan tujuan pembelajaran
b. Merumuskan kompetensi dasar
c. Menyiapkan bahan materi pembelajaran d. Merencanakan dan menyusun
skenario pembelajaran, pengalaman 
belajar serta menentukan metode apa yang akan digunakan

e. Tahap persiapan, dalam hal ini guru melatih siswa cara memegang alat tulis dan menggoreskannya pada buku, tentu saja ada yang kasar dan halus.

f. Menulis pola kalimat sederhana, mengenalkan penulisan huruf cetak dan huruf tegak bersambung. Siswa mencontoh dan melakukan berulang-ulang.

g. Menulis kalimat sederhana

Walaupun tujuan menulis permulaan ini menitikberatkan pada kemampuan menulis dengan tulisan yang terang dan jelas, namun jangan lupa, setiap tulisan disuruh anak membacanya kembali. Ingat, pelajaran membaca dengan menulis harus sejalan.

Begitulah seterusnya sampai semua huruf dapat ditulis oleh siswa anak. Tetapi ingat, semuanya disajikan dalam bentuk kalimat (metode SAS). Contoh kalimat yang dipakai, guru bebas berekspresi mengubah, asal mengandung huruf yang akan diajarkan. Begitu juga dengan penulisan huruf kapital, kata yang berawalan dan berakhiran, diftong, tanda baca, dan lain-lain itu dapat dimiliki dengan latihan dan bimbingan yang intensif.

\section{Pembelajaran Ejaan}

Dalam komunikasi secara lisan, dengan mudah kita dapat memahami gagasan yang di sampaikan oleh pembicara, sebab gerak, pandangan mata, ekspresi wajah, intonasi dan sebagainya menunjang kejelasan maksud yang diungkapkan melalui bahasa. Hal-hal yang mendukung kejelasan itu tidak terdapat dalam komunikasi tulis. Ketiadaan itu tentu menyulitkan komunikasi dan besar kemungkinan akan menimbulkan kesalahpahaman. Di sini ejaan dan tanda baca berperan sampai batas-batas tertentu menggantikan beberapa unsur nonbahasa yang diperlukan untuk memperjelas gagasan.

Materi tentang ejaan yang diberikan ini dilanjutkan di kelas berikutnya. Karena merupakan dasar dan sangat menentukan dalam menulis lanjut, pokok bahasan ejaan hendaknya betul-betul diberikan sampai tuntas.

Guru harus sering memberikan contoh-contoh atau tugas kerja siswa, agar siswa melakukan pengalaman belajar yang berarti.

Tujuan pengajaran ejaan, tentulah mengharapkan siswa mampu menuliskan huruf, kata, tanda baca, ataupun kalimat sesuai dengan pedoman ejaan yang berlaku. Siswa diharapkan dapat menggunakan dan menuliskan huruf, kata, unsur serapan, dan tanda baca dengan benar dan sesuai dengan pedoman yang berlaku. Penekanannya di sini bukanlah pada pengetahuan tentang ejaan (teori), tetapi penerapannya. Tentu cara mengajarkannya berbeda dengan siswa sekolah lanjutan.

\section{Pembelajaran Menulis Lanjutan}

Setelah siswa memiliki kemampuan menulis permulaan dan penerapan ejaan, barulah dilanjutkan dengan menulis lanjut. Menulis lanjut ini baru dimulai di kelas IV. Siswa dituntut mampu melahirkan gagasangagasannya dengan bahasa Indonesia yang baik dan benar.

Seperti sudah dibicarakan, secara garis besarnya pokok bahasan menulis lanjut dapat dikelompokkan menjadi:

a. Pengembangan paragraf

Kemampuan menulis bukanlah kemampuan yang diwariskan secara turun-temurun, tetapi merupakan hasil 
proses belajar-mengajar dan ketekunan berlatih. Kemampuan ini berkaitan erat dengan kemampuan membaca. Penulis yang baik biasanya juga pembaca yang baik.

Kemampuan menerapkan ejaan sesuai dengan pedoman yang berlaku, kemampuan memilih kata dengan tepat, kemampuan membuat kalimat yang efektif, belum sepenuhnya menjamin seseorang mampu menulis. Dalam menuangkan pikiran atau gagasan, Kita pun dituntut mampu menghubungkan kalimat dengan kalimat dalam satukesatuan yang padu. Hubungan itu menyatakan satu kesatuan yang diikat oleh struktur kebahasaan dan kesatuan yang logis.

Dalam tulis-menulis atau karangmengarang ikatan ini dilahirkan dalam bentuk paragraf.

Paragraf merupakan karangan yang paling pendek atau paling singkat. Dengan paragraf kita dapat membedakan di mana suatu gagasan dimulai dan berakhir. Kita akan kepayahan membaca sebuah tulisan atau buku kalau tidak ada paragraf, karena kita seolah-oleh dipaksa untuk membaca terus-menerus sampai selesai. Kita pun akan susah berkonsentrasi membaca dari satu gagasan ke gagasan lain. Dengan adanya paragraf kita dapat berhenti sebentar sehingga dapat memusatkan pikiran kita kepada gagasan yang tergantung dalam paragraf itu.

Sebuah paragraf dibangun oleh beberapa kalimat yang saling berhubungan karena hanya membicarakan satu gagasan pokok/topik atau satu pikiran. Semua kalimat dalam paragraf harus membicarakan gagasan pokok tersebut. Tidak ada satu kalimat pun yang tidak berkaitan dengan gagasan pokok
Seperti kita ketahui, dalam pengembangan paragraf, siswa dituntut menerapkan kemampuannya tentang masalah yang berkaitan dengan faktor kebahasaan. Pada waktu ini, siswa dituntut mampu menerapkan ejaan sesuai dengan pedoman, mampu memilih kata yang paling tepat, mampu membuat kalimat yang efektif, dan mampu menghubung-hubungkan kalimat dengan kalimat. Penekanan latihannya tentulah pada hal-hal di atas.

Ada beberapa syarat membentuk paragraf yaitu :

1) Unsur Kesatuan, tidak boleh terdapat unsur-unsur yang sama sekali tidak berhubungan dengan topik atau gagasan. Penyimpangan akan menyulitkan pembaca.

2) Unsur kepaduan, adanya koherensi antar kalimat atau hubungan timbal balik dan tidak berdiri sendiri.

3) Unsur kelengkapan, berisi kalimatkalimat penjelas untuk menunjang kejelasan topik utama.

Sebelum mengarang satu paragraf, siswa diarahkan dulu menyusun kerangka paragraf. Tentu topiknya disesuaikan dengan siswa Sekolah Dasar. Kemudian, dalam pengembangannya diperhatikan adalah ketiga persyaratan paragraf, yaitu: unsur kesatuan, kepaduan dan kelengkapan. Contoh:

Kerangka Paragraf :

Pikiran Utama : Pekarangan rumah yang bersih

Pikiran Penjelas : Halaman depan, Halaman samping, Tanaman Pemeliharaan

Contoh Pengembangannya: "Pekarangan rumah Nenek Romlah bersih sekali. Halaman depan yang sangat luas, sangat terpelihara dan bersih. Begitu pula halaman samping yang tidak begitu luas. 
Jurnal Guru Kita (JGK). Vol 1 (2) Maret 2017, hlm. 26-39

Tanaman yang ada di halaman sang at subur dan terpelihara. Nenek Romlah memang sangat rajin membersihkan halamannya dan memupuk tanamannya".

Yang penting kita perhatikan, satu paragraf itu hanya mengandung satu topik. Kemudian, antara kalimat dengan kalimat saling berhubungan. Di samping itu, gagasan pokok atau pikiran utama itu dikembangkan secara lengkap.

Dalam pengembangan paragraf, pikiran utama dapat dipilih siswa dan dapat pula ditentukan guru. Mulailah dengan hal-hal yang dikenal siswa, misalnya lingkungan rumah, sekolah dan sebagainya.

b. Menulis bermacam-macam surat dan laporan

Surat adalah suatu sarana untuk menyampaikan informasi tertulis kepada pihak lain. Istilah surat-menyurat mengandung pengertian hubungan antara satu pihak dan pihak lain dengan perantaraan surat. Jadi, surat merupakan salah satu kegiatan berbahasa yang dilakukan dalam komunikasi tertulis.

Untuk siswa Sekolah Dasar, pertama kali dilatihkan surat pribadi. Sesuai dengan kebutuhan siswa, surat pribadi ini ditujukan kepada orang tua, teman, yang isinya bermacam-macam. Yang perlu kita perhatikan adalah pertama isi surat, dan yang kedua bahasa surat yang termasuk pilihan katanya. Kemudian, salam pembuka dan penutup. Jadi unsurunsur sebuah surat hendaknya sudah lengkap.

c. Pengembangan bermacam-macam karangan

Pada dasarnya semua tulisan dapat dikelompokkan ke dalam empat macam karangan, yaitu:
1) Narasi (cerita)

2) Eksposisi (Paparan)

3) Deskripsi (Lukisan)

4) Argumentasi (Persuasi)

a) Narasi (Cerita)

Narasi merupakan suatu bentuk wacana yang berusaha mengisahkan suatu kejadian atau peristiwa sehingga tampak seolah-olah pembaca melihat atau mengalami sendiri peristiwa itu. Oleh karena itu, unsur yang paling penting dalam sebuah narasi adalah unsur perbuatan atau tindakan yang terjadi dalam suatu rangkaian waktu. Apa yang telah terjadi tidak lain adalah tindak-tanduk yang dilakukan oleh orang-orang atau tokoh-tokoh dalam suatu rangkaian waktu atau dengan kata lain mengisahkan suatu kehidupan yang dinamis dalam suatu rangkaian waktu. Jadi, narasi adalah suatu bentuk wacana yang sasaran utamanya adalah tindak tanduk yang dijalani dan dirangkaikan menjadi sebuah peristiwa yang terjadi dalam suatu kesatuan waktu. Atau suatu bentuk wacana yang berusaha menggambarkan dcngan sejelas-jelasnya kepada pembaca suatu peristiwa yang telah terjadi. Gorys Keraf mengemukakan narasi berusaha menjawab pertanyaan, "Apa yang telah terjadi?" (Keraf, 1983).

$\begin{array}{lcr}\text { b) Deskripsi } & & \\ \quad \text { Deskripsi } & \text { pada } & \text { hakikatnya } \\ \text { merupakan } & \text { usaha } & \text { untuk } \\ \text { menggambarkan } & \text { dengan } & \text { kata-kata }\end{array}$
wujud atau sifat lahiriah suatu objek. Melalui deskripsi, seorang penulis berusaha memindahkan kesan-kesan hasil pengamatan dan perasaannya kepada pembaca dengan membeberkan sifat dan semua perincian yang ada pada sebuah objek.

Sebuah objek deskripsi tidak hanya terbatas pada apa yang dapat dilihat, didengar, dicium, dirasa, dan di raba, 
tetapi seorang penulis deskripsi juga harus dapat mendeskripsikan perasaan hati, misalnya perasaan takut, cemas, enggan, jijik, cinta, kasih, sayang, haru, benci, dan sebagainya. Demikian pula tentang suasana yang timbul pada suatu peristiwa, misalnya panasnya sinar matahari, dingin yang mencekam, panasnya bara, dapat pula dideskripsikan oleh seorangpenulis. Jadi, deskripsi pada hakikatnya merupakan suatu usaha untuk menggambarkan dengan kata-kata, wujud atau sifat lahiriah dari suatu objek. Deskripsi menekankan pada kesan dengan berusaha menyadarkan lukisan yang dirangkai dengan katakata. Seluruh pancaindera dituntut untuk aktif. Penulis berusaha supaya pembaca seolah-olah melihat apa yang disaksikannya, mencium apa yang dibauinya, mendengar apa yang didengar, dan merasakan apa sedang dirasakan penulis. Melalui rangkian kata-kata penulis berusaha menggambarkan sesuatu sejelas mungkin dan menggugah pancaindera pembaca sehingga apa yang dilukiskan seolah-olah terpancang di depan mats pembaca. Dengan adanya deskripsi pembaca dapat membayangkan bagaimana indahnya sebuah pantai dengan deburan ombak seperti yang digambarkan penulis, atau dapat membayangkan bagaimana licinnya jalan di sebuah pegunungan, walaupun pembaca belum pernah mengalaminya.

Namun karangan deskripsi tidak dapat berdiri sendiri. Ia terjalin dalam narasi dengan tugas untuk menghidupkan ceritera. Ia ada dalam paparan untuk memperjelas paparan dan ia ada dalam argumentasi untuk memperkuat bukti-bukti atau alasanalasan.

\section{c) Eksposisi}

Paparan merupakan karangan yang berusaha menerangkan atau menjelaskan sesuatu yang dapat memperluas pandangan atau pengetahuan seseorang. Paparan sering digunakan dalam menyampaikan uraian-uraian ilmiah, ilmiah populer, dan uraian ilmiah lainnya yang pada prinsipnya tidak berusaha mempengaruhi pendapat orang lain. Tulisan ilmiah populer yang banyak kita temui dalam surat kabar harian, mingguan, atau majalah bulanan, biasanya disajikan dalam bentuk paparan. Pembaca sama sekali tidak dipaksa menerima pendapat penulis, tetapi setidaknya pembaca mengetahui bahwa penulis berpendapat atau berpendirian demikian.

Selain dari uraian yang bersifat ilmiah, semua tulisan yang berisi penjelasan atau informasi dapat digolongkan kedalam paparan. Misalnya berita dalam surat kabar, majalah, yang pada prinsipnya berusaha menguraikan dan menjelaskan suatu pokok pikiran yang dapat memperluas pengetahuan dan pandangan seseorang. Untuk mencapai tujuan tersebut, penulisan paparan harus betul-betul mengetahui dan menguasai objek yang akan dipaparkan.

Ada beberapa cara yang dapat digunakan dalam pengembangan paparan (eksposisi). Walaupua ada beberapa cara, namun bukan berarti tiap karangan hanya menggunakan satu metode saja, atau sebaliknya menggunakan semua metode. Ada karangan yang mungkin cocok dengan metode tertentu, atau bagian tertentu menggunakan metode tertentu dan bagian lain metode lain. Jadi, mungkin saja satu karangan menerapkan beberapa metode, atau satu metode sebagai kerangka dasar untuk seluruh karangan. 
Tetapi setiap pengarang bebas memilih metode yang dianggapnya paling cocok untuk keseluruhan karangannya atau untuk bagian tertentu.

Cara-cara atau metode-metode yang biasa digunakan untuk pengembangan paparan ialah:

(1) metode identifikasi

(2) metode perbandingan

(3) metode ilustrasi atau eksemplikasi

(4) metode klasifikasi

(5) metode definisi, dan

(6) metode analisis, yang dapat dibagi menjadi:
(a) analisis bagian
(b) analisis fungsional
(c) analisis proses
(d) analisis kausal (Gorys Keraf, 1982)

\section{d) Argumentasi}

Argumentasi merupakan karangan yang berusaha membuktikan sesuatu dengan mengemukakan alasan-alasan yang meyakinkan. Di sini siswa dituritut mampu menghubung-hubungkan fakta secara logis untuk sampai pada sebuah kesimpulan yang meyakinkan. Siswa dilatih bernalar secara logis. Banyak topik yang dapat dikembangkan menjadi sebuah argumentasi. Misalnya: "Got Harus Selalu Bersih", "Kita Harus Mandi Setiap Hari", "Disiplin dapat Meningkatkan Prestasi", "Ketahanan Sekolah Perlu Ditingkatkan" dan sebagainya.

Kalau siswa mengembangkan topik "Got Harus Selalu Bersih", tentu ia dituntut dapat mengemukakan alasanalasan yang dapat meyakinkan pembaca. d. Menulis puisi dan naskah drama.

Anak-anak sangat menyayangi irama termasuk puisi. Berikanlah puisipuisi yang sederhana. Dapat juga diambil dan lagu anak-anak.

Perhatikan contoh berikut!
Jangan suka makan ketimun

Ketimun itu banyak getahnya

Tidak baik duduk melamun

Melamun itu tidak ada gunanya. Jelaskan, bahwa bentuk puisi di atas bernama pantun. Jelaskan mana sampiran dan mana isi. Demikian juga persajakannya.

Carilah contoh puisi lain, kemudian jelaskan puisi tesebut berbentuk apa dan suruh siswa menceritakan isinya dengan bahasanya sendiri. Kemudian, suruhlah siswa menulis puisi sendiri.

Mengenai pokok bahasan menulis naskah drama, tentu siswa dilatih menulis dialog. Berilah contoh terlebih dahulu, kemudian suruh siswa membaca dan menyalinnya. Kemudian, barulah diberikan sebuah topik dan siswa disuruh menyusun dialognya. Penekanannya di sini cara menulis dialog. Sumbernya bermacam-macam. Mulailah dan lingkungan siswa. Misalnya tentang kegiatan di hari libur, rencana kegiatan ekstrakurikuler di sekolah, percakapan dengan anaknya sepulang sekolah dan lain-lain.

e. Menuliskan Cerita Anak

Cerita anak adalah cerita yang ditulis menggunakan sudut pandang anak. Artinya, jika cerita adalah pengalaman sehari-hari, maka pengalaman itu harus ditulis dengan menggunakan sudut pandang anak. Jika cerita itu adalah gambaran sehari-hari, maka gambaran kehdupan itu harus ditulis dengan sudut pandang anak. Jika cerita itu adalah dongeng atau fantasi negeri-negeri entah di mana, maka itu harus diceritakan dengan sudut pandang anak .

Cerita anak termasuk cerita fiksi baru. Karakteristik cerita anak tidak berbeda dengan karya sastra lainnya. Perbedaan cerita anak dengan cerita fiksi, yaitu letak fokus perhatiannya. Fokus perhatian cerita anak pada anak- 
anak. Tokoh dalam cerita anak oleh siapa saja, tetapi tetap harus tokoh anakanak dan tokoh tersebut menjadi tokoh utama dalam cerita. Tokoh cerita anak dapat juga berupa benda mati, tanaman, aneka satwa yang seolah-olah bertingkah laku seperti perilaku manusia. Unsur cerita anak merupakan satu karya yang utuh dan terdiri atas unsur-unsur yang membentuk atau membangun cerita itu sendiri disebut unsur intrinsik. Unsur-unsur intrinsik cerita anak meliputi :

a. Gaya dan Bahasa

Bahasa adalah diksi, kalimat, dan wacana yang akan digunakan sebagai. alat untuk bercerita, sedangkan gaya adalah cara menggunakan bahasa. Keduanya saling berkaitan dan menjadi unsur utama . Bahasa yang sesuai dengan sudut pandang anak adalah bahasa yang bisa dipahami anak. Anak akan memahami bahasa melalui satuansatuan bahasa yang memiliki arti dalam jangkauan pengetahuan anak-anak.

Misalnya :

Dua bulan yang lalu, kakek Fina datang dari Jakarta. Fina sangat senang. Fina menyediakan singkong goreng dan ikan emas kegemaran kakek. Ketika kakek pulang ke Jakarta, Fina merasa kehilangan .

b. Tema

Tema adalah gagasan dasar umum yang menopang sebuah karya sastra yang terkandung di dalam teks sebagai struktur semantis, dan yang menyangkut persamaan-persamaan atau perbedaanperbedaan . Tema cerita anak mengenai keluarga, sahabat, kasih sayang dan sebagainya, tetapi masalah tersebut harus sesuai dengan dunia anak-anak.

\section{c. Tokoh}

Penokohan adalah cara pengarang menggambarkan karakter tokoh-tokoh dalam cerita. Sementara tokoh adalah orang/pelaku yang berperan dalam cerita. Tokoh protagonis yaitu tokoh yang mendukung cerita. Biasanya ada satu atau dua figur tokoh protagonis utama yang dibantu tokoh lain yang terlibat dalam cerita. Tokoh jenis ini biasanya berwatak baik, dan menjadi idola pembaca/pendengar.

Tokoh antagonis yaitu tokoh yang menjadi penentang cerita. Biasanya ada satu atau dua figur tokoh yang menentang cerita. Tokoh jenis ini berwatak jahat dan dibenci oleh pembaca dan pendengar. Tokoh tritagonis yaitu tokoh pembantu (penengah) baik untuk tokoh protagonis maupun antagonis. Contoh tokoh dalam cerita anak Unyil, Kancil,

d. Latar

Latar disini adalah tempat dan atau waktu terjadinya perbuatan tokoh atau peristiwa yang dialami tokoh. Dalam cerita anak, latar difungsikan sebagai tempat an waktu terjadinya peristiwa yang dialami tokoh dalam menghadapi permasalahan.

Misalnya :

Pada hari jum'at sore Inu, Ani, Bonar dan Peter berkunjung ke rumah Ita. Mereka menonton acara cerita anak-anak di TVRI sambil bermain. Ani melihat ada majalah di bawah meja televisi. Diambilnya majalah itu, lalu dibukanya halaman-halaman majalah itu. Dia menemukan puisi. Puisi yang bercerita tentang air .

\section{e. Alur}

Alur merupakan rangkaian peristiwa yang terdapat dalam cerita. Dalam cerita anak, alur untuk sebagian cerita masih sederhana. Kemungkinan ada dua: alur maju, yang banyak terdapat pada cerpen dan novel anak kontemporer, dan alur mundur atau terbingkai, yang banyak terdapat pada dongeng. 
f. Suasana

Suasana adalah keadaan yang terdapat dalam peristiwa-peristiwa cerita. Peristiwa dalam cerita yang merupakan dalam kejadian yang dialami tokoh-tokoh pada suatu latar tertentu sebenarnya membahas pokok permasalahan (tema). Tema inilah yang menjadi nada dasar dari suatu suasana yang diciptakan oleh peristiwa-peristiwa dalam cerita anak. Maka, suasana merupakan suatu efek peristiwa dalam menyampaikan tema .

g. Amanat

Amanat adalah pesan berupa nilainilai yang akan disampaikan cerita kepada pembaca. Amanat cerita anak berangkat dari pokok persoalan yang ada dalam cerita. Jika persoalan tentang persahabatan, kedisiplinan, kerajinan, kesombongan, dan kemalasan, maka amanat cerita juga akan selalu berkaitan dengan hal-hal bersebut. Karena wujud amanat adalah nilai, maka amanat cerita merupakan ajaran-ajaran kebaikan dan ketauladanan.

\section{DAFTAR RUJUKAN}

Affandi M.,B.A. et.al.1989. Belajar Menulis Tegak Bersambung. Klaten: Intan Pariwara.

Akhadiah, Sabarti dkk. 1992. Modul Bahasa Indonesia I, II, III. Depdikbud

Hakikat Pendidikan di
Sekolah Dasar. Proyek
Pembinaan Tenaga Kependidikan
Perg. Tinggi Dep P \& K, 1990 -
1991.

Departemen Pendidikan dan Kebudayaan. Pelajaran Bahasa untuk Sekolah Dasar, Jakarta: Balai Pustaka, 1987.
1986. Kurikulum Sekolah Dasar (SD) Garis-garis Besar Program Pengajaran. Bidang Studi: Bahasa Indonesia, Jakarta: Pusat Pengembangan Kurikulum dan Sarana Pendidikan,

Djuminto. 2004. Bahasa Indonesia untuk Sekolah Dasar Kelas 6. Jakarta: Bumi

Aksara.

Fahmi. 2015. Permasalahan Anak Usia

Dini. Serang: Untirta Press.

Iskandarwassid; Sunendar, Dadang. 2008. Strategi Pembelajaran

Bahasa. Bandung: Remaja Rosdakarya.

Keraf, Gorys. 1981. Argumentasi dan Narasi, Jakarta: Gramedia.

1982. Eksposisi dan Deskripsi. Ende: Nusa Indah,

Kurniawan, Heru. 2013. Menulis Kreatif Cerita Anak. Jakarta: Akadema Permata.

_. 2013. Sastra Anak. Yogyakarta: Graha Ilmu.

Muslich, Masnur. 2007. KTSP Pembelajaran Berbasis Kompetensi dan Kontekstual. Jakarta: Bumi Aksara

Sabarti, A.M.K. Model Pengajaran Bahasa Indonesia. Proyek Pembinaan Tenaga Kependidikan Dikjen Perguruan Tinggi, Dep P \& K, 1990.

Sabarti Akhadiah, Maidar Arsjad, Sakura Ridwan, Pembinaan Kemampuan Menulis Bahasa Indonesia. Jakarta: Erlangga, 1990. 